\title{
Direct Fast Pyrolysis Bio-oil Fuel Cell
}

Neeva Benipal ${ }^{\text {a }}$, Ji Qi ${ }^{\text {a }}$, Patrick A. Johnston ${ }^{\text {b }}$, Jacob C. Gentile ${ }^{\text {a }}$, Robert C. Brown ${ }^{\text {b,c }}$, Wenzhen $\mathrm{Li}^{\mathrm{a}, \mathrm{d}, *}$

${ }^{a}$ Department of Chemical and Biological Engineering, Biorenewables Research Laboratory, Iowa State University, Ames, IA 50011, USA

${ }^{\mathrm{b}}$ Department of Mechanical Engineering, Iowa State University, Ames, IA 50011, USA

${ }^{\mathrm{c}}$ Bioeconomy Institute, Iowa State University, Ames, IA 50011, USA

${ }^{\mathrm{d}}$ Ames Laboratory, USDOE, Ames, IA 50011, USA

*Corresponding Author. Tel: 01-515-294-4582, Email Address: wzli@iastate.edu (W.Li)

Keywords: Fuel cell, Pyrolysis bio-oil, Anion-exchange membrane, Catalysts, Biomass, Renewables

\begin{abstract}
Bio-oil derived from the pyrolysis of lignocellulosic biomass shows a great promise, however, needs further upgrading to potentially serve as an alternative to fossil fuels. Herein, we demonstrate that crude fast pyrolysis bio-oil can be directly used as a fuel for anion exchange membrane fuel cells (AEMFCs) to generate high power density electrical energy at low temperature $\left(\leq 80^{\circ} \mathrm{C}\right)$. A simple aqueous-phase reduction method was used to prepare carbon nanotube $(\mathrm{CNT})$ supported noble metal $(\mathrm{Pt}, \mathrm{Pd}, \mathrm{Au}$, and $\mathrm{Ag}$ ) nanoparticles with average particle
\end{abstract}


sizes: $1.4 \mathrm{~nm}, 2.0 \mathrm{~nm}, 3.8 \mathrm{~nm}$, and $12.9 \mathrm{~nm}$ for $\mathrm{Pt} / \mathrm{CNT}, \mathrm{Pd} / \mathrm{CNT}, \mathrm{Au} / \mathrm{CNT}$, and $\mathrm{Ag} / \mathrm{CNT}$, respectively. Direct fast pyrolysis bio-oil AEMFCs with the Pd/CNT anode catalyst and a commercial Fe-based cathode catalyst exhibit a remarkable peak power density of $42.7 \mathrm{~mW} \mathrm{~cm}$ at $80^{\circ} \mathrm{C}$ using $30 \mathrm{wt} \%$ bio-oil $+6.0 \mathrm{M} \mathrm{KOH}$ electrolyte. Levoglucosan was identified as the major sugar compound with 11.1 wt\% of the bio-oil composition, along with disaccharides, pyrolytic lignin, and oligomer of lignin-derived phenolic compounds. Cyclic voltammetry (CV) studies investigated the electrocatalytic oxidation of high purity levoglucosan over the four noble metal catalysts in half cell, as levoglucosan is the dominant sugar component in bio-oil. $\mathrm{Pd} / \mathrm{CNT}$, compared to other catalysts, displayed the highest activity and lowest onset potential of electrocatalytic oxidation of levoglucosan. AEMFC with high purity sugars shows $\sim 1.2$ to 3 times higher power density than that with fast pyrolysis bio-oil fuel.

\section{Introduction}

Currently biomass-derived fuels (biofuels) are of growing interest, mainly due to increasing concerns of global warming and environmental deterioration [1]. Consumption of fossil fuels contributes to emission of carbon dioxide $\left(\mathrm{CO}_{2}\right)$, nitrogen oxides $\left(\mathrm{NO}_{\mathrm{x}}\right)$, and other greenhouse gases (GHG). Emission of sulfur dioxide also leads to acid rain, causing damage to crops, forests and upsetting the ecosystem equilibrium [2]. To date, over $70 \%$ of electricity has been produced by fossil fuels such as natural gas and coal, while renewable energy accounts only for only about 
$20 \%$ of all generated electricity $[3,4]$. Clean electricity generated from renewable sources, such as solar, wind and biomass is expected to play an important role in future energy landscape, and substantial effort has been spent on research and development directed toward converting biomass into liquid fuels and commodity chemicals [5, 6], but presently they remain more expensive than their counterparts produced from fossil sources.

Fuel cells are considered as one of the most promising electrochemical energy generation devices, which can directly convert renewable resources into electrical power in an environmentally-friendly manner. Today's fuel cells have the capability to ensure energy security, high efficiency, low operating cost, fuel versatility, and pollution-free power, largely because this electrochemical process is not limited by the Carnot theorem [7, 8]. In addition, fuel cells can be used in various scale stationary and mobile systems for quiet and continuous power generation [9]. Direct alcohol fuel cells (DAFCs) have attracted enormous attention as potential power sources, mainly because alcohol as a liquid fuel is easy to transport and convenient to store [10]. However, challenges such as poor oxidation kinetics at the anode, fuel purity requirements, and alcohol crossover limit widespread practical applications of DAFCs technology. Recently, alkaline anion exchange membrane fuel cells (AEMFCs) are emerging quickly as a potential solution to these problems. The electrocatalytic kinetics of both anode (fuel oxidation) and cathode (oxygen reduction) are higher in an alkaline media compared to an acid media due to facile charge transfer and enhanced ion transport. Furthermore, the poison severity of impurities and contaminates on anode catalysts can be greatly alleviated in alkaline environments [11]. To explore more alternatives fuels, several studies have been carried out based on the AEMFC platform using various biorenewable fuels such as glucose [12], cellulose 
[13], and crude glycerol [14]. There is an urgent need to seek widely available and economical biomass-derived oil/fuels for fuel cell applications.

Bio-oil derived from fast pyrolysis of biomass is considered as a promising source of biobased chemicals and biofuels [5, 15-18]. As traditionally recovered, bio-oil is an emulsion of water-insoluble phenolic compounds derived from lignin in an aqueous phase of water-soluble oxygenated compounds derived mostly from carbohydrate mixtures. This emulsion contains hundreds of chemicals that are difficult to separate by traditional recovery techniques such as atmospheric, fractional, steam, and vacuum distillations [1]. Pollard and Brown [19] recently developed a novel bio-oil recovery method that recovers bio-oil as stage fractions with distinct chemical and physical properties using combinations of condensers with carefully-controlled coolant temperatures and electrostatic precipitators. These fractions consist of heavy ends, middle fraction, and light ends. The heavy ends can be further separated into phenolic oil and anhydrosugars, the middle fraction is mostly phenolic monomers and furans, and the light ends are an aqueous fraction containing light-oxygenated compounds such as acetic acid [20]. Fast pyrolysis bio-oil has the potential to substitute for fossil liquid fuels after it has been upgraded by catalytic cracking, catalytic hydrogenation, or stream reforming [21]. Bio-oil contains 40\% dryweight oxygen, while petroleum-based fuels contains around $1 \%$, so these bio-oil must be upgraded to be rightfully considered as an equivalent replacement; because highly oxygen-rich hydrocarbons bio-oil are of inferior quality for direct use as transportation fuels in combustion engines, but they may be directly served as a fuel in alkaline membrane fuel cells to generate electricity.

It should be noted that most previous AEMFC studies have been focused on high-purity fuels such as glycerol [12, 22, 23], ethanol [24], methanol [25], ethylene glycol [26], and glucose [27]. 
Biofuel cells with enzymatic catalysts can directly employ complex crude biomass-feedstock and waste water, but the generated power density is generally lower than $1 \mathrm{~mW} / \mathrm{cm}^{2}$, thus limiting biofuel application to environmental remediation rather than energy generation applications [28]. In the past, our group has used crude glycerol (88 wt $\%)[29,30]$ as feedstock for AEMFCs and has shown a peak power density of $268 \mathrm{~mW} \mathrm{~cm}^{-2}$; this approach can be readily expanded to study more complex compound bio-oil (a mixture of over 400 compounds) as a potentially feasible fuel for AEMFCs. To the best of our knowledge, no work has yet been done on direct fast pyrolysis bio-oil for use as a fuel in AEMFCs, therefore, this study of AEMFCs directly using bio-oil establishes a generalized approach to using bio-oil to produce electrical power without the need for extensive purification of the initial raw feedstock fuel. We report a direct bio-oil AEMFC using a noble metal Pd/CNT anode catalyst to achieve a peak power density of $42.7 \mathrm{~mW} \mathrm{~cm}{ }^{-2}$ at $80^{\circ} \mathrm{C}$. The effects of operation conditions such as the bio-oil concentration, temperature, and $\mathrm{KOH}$ concentration on cell performance were also studied along with the analysis of bio-oil compositions. The electrocatalytic activities of four noble metal catalysts $\mathrm{Pd} / \mathrm{CNT}, \mathrm{Ag} / \mathrm{CNT}, \mathrm{Au} / \mathrm{CNT}$, and $\mathrm{Pt} / \mathrm{CNT}$ with respect to oxidation of high purity levoglucosan (a major sugar component) were studied. The comparison of fast pyrolysis bio-oil AEMFC with high-purity sugar-fed AEMFC was investigated in both half-cell and single-cell systems.

\section{Experimental}

\section{$2.1 \quad$ Chemicals}

Palladium (II) nitrate dihydrate, silver nitrate, gold (III) chloride, polytetrafluoroethylene (PTFE), 1-propanol (99.5\%), sodium borohydride (99\%), sodium citrate dihydrate (99\%), glucose (99\%), sucrose (99\%), potassium hydroxide (85\%), and potassium sulfate (99\%) were purchased from Sigma-Aldrich. Carboxyl-group functionalized multi-walled carbon nanotubes 
(8-15 nm outer diameter, 0.5-2 $\mu \mathrm{m}$ length) were procured from Cheaptubes Inc. The cathode catalyst 4020 was obtained from Acta, Inc, and levoglucosan, cellobiosan, and maltosan were received from Carbosynth. Xylose was purchased from Thermo Fisher Scientific. Stage fraction 2 bio-oil was obtained from the Iowa State University BioCentury Research Farm. All chemicals were used as received without further purification.

\subsection{Catalyst Synthesis and physical characterizations}

Carbon nanotube-supported $\mathrm{Pd}, \mathrm{Pt}, \mathrm{Ag}$, and $\mathrm{Au}$ nanoparticles were synthesized by an aqueous-phase reduction method [29, 31]. An aqueous-phase reduction method involves chemical reduction of dissoluble metal precursors in aqueous phase to the nucleus, controlled growth to ultimately-desired metal nanoparticles in the absence of stabilizing agents, and deposition on an appropriate carbon support. Concisely, to make Pd/CNT, Palladium (II) nitrate (105 mg) was dissolved in deionized water $(1500 \mathrm{~mL})$, followed by stirring at a speed of 600 rpm to ensure appropriate dispersion of the solution. Sodium citrate dihydrate $(200 \mathrm{mg})$ and sodium borohydride $(40 \mathrm{mg})$ were separately dissolved in deionized water $(50 \mathrm{~mL})$ and then carboxyl-group functionalized multiwall carbon nanotubes $(181 \mathrm{mg})$ were dispersed in $100 \mathrm{~mL}$ of deionized water by ultrasonication; all were then combined in a solution to reduce metal precursors and to deposit Pd nanoparticles onto the surface of the CNT. The final product $\mathrm{Pd} / \mathrm{CNT}(20 \%)$ was cleaned with an additional $1 \mathrm{~L}$ of deionized water, collected by vacuum filtration, and dried overnight in a vacuum oven. Pt/CNT, Ag/CNT, and Au/CNT were synthesized via a similar process as that used for Pd/CNT but with different metal precursors. The morphology and structure of the as-prepared catalysts were analyzed by transmission electron microscopy (TEM) and X-ray diffraction (XRD). The TEM images were collected on a JEOL JEM -4000 FX with an accelerating voltage of $200 \mathrm{kV}$. A Scintag XDS-2000 $\theta / \theta$ 
diffractometer $(\mathrm{Cu} K \alpha$ radiation $(\lambda=1.5406 \AA)$ with $35 \mathrm{~mA}$ filament current and $45 \mathrm{kV}$ tube voltage was used to collect XRD patterns at a continuous scan rate of 1.2 degrees per minute. The mean crystallite size of all these noble metal catalysts were calculated using the (220) peak based on the Debye-Scherrer formula, while lattice constants were calculated using the (220) peak based on a combination of Bragg's law and the relationship between lattice and crystallattice spacing as follows:

$$
L=\frac{0.9 \lambda_{K \alpha}}{B_{2 \theta} \cos \theta_{\max }}
$$

where $\mathrm{L}$ is the mean crystallite size, $\lambda_{K \alpha}$ is the $\mathrm{X}$-ray wavelength (1.5406 $\AA$ ), B is the full width of the peak (rad) at half-maximum (FWHM), and $\theta_{\max }$ is the Bragg angle (rad) of (220) peak position.

\section{$2.3 \quad$ Half-cell tests}

A traditional three-electrode water-jacket-integrated glass cell (AFCELL3, Pine Instrument) with a glassy carbon working electrode (AFE3T050GC, Pine Instrument), a $\mathrm{Hg} / \mathrm{HgO}$ reference electrode (MMO, CHI152, $\mathrm{CH}$ Instruments), and a platinum wire counter electrode (AFCTR1, Pine Instrument), were used for cyclic voltammetry (CV). All tests were prepared and performed at ambient temperatures and all potentials were specified to $\mathrm{MMO}(1.0 \mathrm{M} \mathrm{KOH}$, $0.098 \mathrm{~V}$ vs. SHE). The prepared catalysts were dispersed by ultrasonication in 1-propanol to form a uniform ink $\left(0.5 \mathrm{mg} \mathrm{mL}^{-1}\right)$. The working electrode was prepared by polishing a glassy carbon electrode (GCE) with alumina micropolish solution and grinding paper to produce a mirror-polished surface. $10 \mu \mathrm{L}$ of ink were deposited drop wise onto the surface of GCE and the electrolytes were composed of $1.0 \mathrm{M} \mathrm{KOH}+0.1 \mathrm{M}$ glucose, levoglucosan, or sucrose in 
deionized water. Cyclic voltammetry was performed at a constant sweep rate of $50 \mathrm{mV} \mathrm{s}{ }^{-1}$ with nitrogen gas purging.

\section{$2.4 \quad$ Single cell tests}

Fuel cell tests were performed on a Scribner Fuel Cell System 850e (Scribner Associates, USA), [29, 32, 33]; the fuel cell fixture with an active area of $5 \mathrm{~cm}^{2}$ was purchased from Fuel Cell Technologies, Inc. The anode catalyst layers were prepared by spraying catalyst ink onto untreated carbon cloth with catalyst loading of $0.5 \mathrm{mg}_{\text {metal }} \mathrm{cm}^{-2}$ with a binder ratio of 9:1 PTFE. The cathode catalyst substrate was constructed by spraying $3 \mathrm{mg} \mathrm{cm}^{-2}$ non-noble metal loading commercial catalyst (4020 Acta) with an ionomer ratio of 7:3 (AS-4, Tokuyama Corp.) on an anion exchange membrane (A901, Tokuyama Corp). Liquid fuel was pumped into the anode compartment at a flow rate of $4.0 \mathrm{~mL} \mathrm{~min}^{-1}$ while high purity $\mathrm{O}_{2}$ was fed into the cathode compartment at a flow rate of $200 \mathrm{~mL} \mathrm{~min}^{-1}$ under a backpressure of $0 \mathrm{psig}$. The liquid fuel, the $\mathrm{O}_{2}$, and the reactor were maintained at constant temperature.

\subsection{Chemical Analysis}

\subsubsection{High Performance Liquid Chromatography}

Non-volatile sugars were characterized using an HPLC equipped with a refractive index (RI). A Bio-Rad Aminex HPX-87P with a guard column was used in the set-up. The column temperature was $75^{\circ} \mathrm{C}$ with a deionized-water flow rate of $0.6 \mathrm{~mL} / \mathrm{min} 18.2 \Omega$. The RI detector required calibration for non-volatile sugars diluted with deionized water into five concentrations (0-10 mg/mL). Approximately $1.0 \mathrm{~g}$ of bio-oil sample was dissolved in $5 \mathrm{~mL}$ of deionized water and thoroughly mixed with a vortex mixer for $20 \mathrm{~min}$. The well-mixed solution was then filtered through a Whatman ${ }^{\circledR} 0.45 \mu \mathrm{m}$ glass microfiber filter and a $25 \mu \mathrm{L}$ sample was injected into the 
HPLC; the total run for time each sample was $70 \mathrm{~min}$. The bio-oil chemical analysis used methods similar to those developed by Pollard [19] and Choi [34].

\subsubsection{Ion Chromatography}

Thermally labile organic acids were characterized by Ion Chromatography (IC) using a Dionex ICS3000 equipped with a conductivity detector and an Anion Micromembrane Suppressor AMMS-ICE 300. The suppressor regenerant was $5 \mathrm{mM}$ tetrabutylammonia hydroxide at a flow rate of $4-5 \mathrm{~mL} / \mathrm{min}$. The mobile phase utilized $1.0 \mathrm{mM}$ heptaflourobutyric acid in an IonPac® ICE-AS1 analytical column at a flow rate of $0.120 \mathrm{~mL} / \mathrm{min}$ at $19^{\circ} \mathrm{C}$. The diluted mixture was filtered through a Whatman ${ }^{\circledR} 0.45 \mu \mathrm{m}$ glass microfiber filter and $25 \mu \mathrm{L}$ were injected into the IC; the total run time for each sample lasted $70 \mathrm{~min}$.

\subsubsection{Gas Chromatography}

Volatile compounds in the bio-oil were characterized by Gas Chromatography using a Mass Spectrometer (GC-MS) for identification. The column used for this setup was a Zebron ZB-1701 coated with 14\% cyanopropylphenyl and 86\% dimethylpolysiloxane with dimensions of (60 m x $0.25 \mathrm{~mm}$ ID x 0.25 um film thickness). The oven was programmed to hold a steady temperature at $35^{\circ} \mathrm{C}$ for $3 \mathrm{~min}$, ramp up at $5^{\circ} \mathrm{C} / \mathrm{min}$ to $300^{\circ} \mathrm{C}$, and then hold steady for $4 \mathrm{~min}$. The injector of $\mathrm{GC}$ was maintained at $300^{\circ} \mathrm{C}$ and engaged a split ratio of $30: 1$. The flow rate of helium carrier gas was $1 \mathrm{~mL} / \mathrm{min}$. The mass spectrometer was configured for electron impact ionization, with a source/interface temperature of $280^{\circ} \mathrm{C}$. Full-scan mass spectra were acquired from 35 to $650 \mathrm{~m} / \mathrm{z}$ at a scan rate of $0.5 \mathrm{~s}$ per scan, and compounds were identified using a NIST mass spectra library search consistent with the literature.

\subsubsection{Proton Nuclear Magnetic Resonance}


${ }^{1} \mathrm{H}$ NMR spectra were collected with a Bruker $600 \mathrm{MHz}$ NMR (AVIII600); the temperature was regulated to $25^{\circ} \mathrm{C}$ during the acquisition and ${ }^{1} \mathrm{H}$ NMR spectra were acquired at room temperature. The bio-oil sample preparation was prepared by drying 50-100 mg of bio-oil for 48 hours. The dried sample was reconstituted with $1 \mathrm{~mL}$ Deuterium oxide and the resultant solution was filtered with $0.2 \mu \mathrm{m}$ filter paper. The data was analyzed using MestReNova version 8.1 software.

\section{Results and discussion}

\subsection{Physical characterization of catalysts}

Fig. 1. (a-d) shows the TEM images and the corresponding metal particle size histograms of $\mathrm{Pt}, \mathrm{Pd}, \mathrm{Au}$, and $\mathrm{Ag}$ nanoparticles supported on CNTs. It is observed that well-dispersed metal particles uniformly deposited on the CNT support, and the average particle sizes, determined by randomly measuring 100 particles, were $1.4,2.0,3.8$, and $12.9 \mathrm{~nm}$ for $\mathrm{Pt} / \mathrm{CNT}, \mathrm{Pd} / \mathrm{CNT}$, $\mathrm{Au} / \mathrm{CNT}$, and $\mathrm{Ag} / \mathrm{CNT}$, respectively. The particle size distributions are fairly narrow: 0.5-4.0 nm for Pt, 1.0-4.0 nm for $\mathrm{Pd}, 2.0-6.5 \mathrm{~nm}$ for $\mathrm{Au}$, except for Ag: 6-22 nm. Roughly big particle agglomerations were found on Ag/CNT sample. Fig. 1 (e) depicts the XRD patterns of Pt/CNT, Pd/CNT, Au/CNT, and Ag/CNT. The XRD patterns show that the metal particles have a facecentered cubic (FCC) structure, with diffraction peaks of (111), (200), (220), and (311) facets, respectively. The mean crystal size values, calculated from using the Debye-Scherrer formula [35-37], were $1.3 \mathrm{~nm}, 2.0 \mathrm{~nm}, 4.1 \mathrm{~nm}$, and $13.9 \mathrm{~nm}$ for Pt/CNT, Pd/CNT, Au/CNT, and $\mathrm{Ag} / \mathrm{CNT}$, respectively, in good agreement with the TEM results. The aqueous-phase reduction method used in this study can prepare very small Pt and Pt nanoparticles under these conditions, however, lead to relatively large Au and Ag nanoparticles, and their optimal synthesis conditions need to be further optimized. Ag precursor is not fully reduced by sodium borohydride (reducing 
agent) due to $\mathrm{Ag}(+0.80 \mathrm{~V})$ having a lower redox potential than $\mathrm{Pt}(+1.20 \mathrm{~V}), \mathrm{Pd}(+0.99 \mathrm{~V})$, and $\mathrm{Au}(+1.50 \mathrm{~V})$. There is also a lack of surfactant (capping agent) in an aqueous-phase reduction method. The surface energy is one of the most important factors affecting the average particle size of the nanoparticles, especially when no strong capping agent is added during preparation. As can be seen in Fig. S1 and Fig. S2 of SI, the surface free energy is a logarithmic function of the number of atoms presented in the particle. When the surface free energy of a Pt, $\mathrm{Pd}, \mathrm{Au}$, and $\mathrm{Ag}$ particle is relatively stable, the total energy required follows the sequence $\mathrm{Pt}>\mathrm{Pd}>\mathrm{Au}>\mathrm{Ag}$. The more energy required, the harder for the atoms to agglomerate. Therefore, the average particle size sequence is $\mathrm{Ag}>\mathrm{Au}>\mathrm{Pd}>\mathrm{Pt}$.

\subsection{Compositional analysis of bio-oil fraction}

Due to bio-oil complexity, bio-oil fractions obtained from fast pyrolysis were analyzed using a broad range of analytical techniques. Significant process descriptions of various analytical techniques dealing with analysis of bio-oil have been reported in the literature [17, 38, 39]. In this study, to understand and design an AEMFC with fast pyrolysis bio-oil, it was necessary to obtain knowledge of major and active components of bio-oil. HPLC was used to detect non/semi volatile sugars with high molecular weight compounds, such as levoglucosan, cellobiosan, and xylose. Levoglucosan was found to be the major identified sugar compound, representing $11.1 \mathrm{wt} \%$ of the bio-oil. IC rather than gas chromatography was used to detect carboxylic acids because of thermal instability of organic acids. The bio-oil consisted of approximately $3.3 \mathrm{wt} \%$ of organic acids, including acetic, propionic, glycolic and formic acids. Table 1 lists quantified distributions of sugars and organic acids using HPLC and IC. The complete quantification was done using IC and HPLC for detection of carboxylic acids and heavy sugars such as mono/disaccharides. 
Table 1. Distributions of fast pyrolysis bio-oil by HPLC and IC

\begin{tabular}{lc}
\hline Compounds & wt \% \\
\hline HPLC detectables & \\
Cellobiose & 0.35 \\
Cellobiosan & 3.35 \\
Xylose & 2.30 \\
Galactose & 0.50 \\
Levoglucosan & 11.10 \\
\hline IC detectables & \\
Glycolate & 1.35 \\
Formate & 0.75 \\
Acetate & 0.56 \\
Propionate & 0.67 \\
\hline
\end{tabular}

GC was used to characterize volatile compounds of bio-oil. The resulting analysis for the bio-oil, as shown in Table S1 of Supplementary Information (SI), demonstrated that the majority of identified compounds from GC are in the categories of furans, ketones, hydroxylaldehydes, alcohols, carboxylic acids, and phenolics. The compound identification from GC was relatively consistent with previous work by Brown et al. [19, 20,34]. Volatile compounds present in the bio-oil detected by GC were in very small quantities, less than $0.01 \mathrm{wt} \%$, so in this analysis further detailed quantitative identification of compounds in the bio-oil was not intended to be exhaustive. Further investigations were carried out on analysis of bio-oil by proton nuclear magnetic resonance $\left({ }^{1} \mathrm{H}\right.$ NMR) spectroscopy to confirm the identification of levoglucosan present in the bio-oil. Fig. S3 of SI shows ${ }^{1} \mathrm{H}$ NMR spectra to confirm the identification of levoglucosan as the major component of crude bio-oil.

\subsection{AEMFC with direct fast pyrolysis bio-oil}

\subsubsection{Effect of catalyst on AEMFC performance}

Our primary goal is to explore the feasibility of low temperature AEMFC with noble metal catalysts for direct electricity generation from crude fast pyrolysis bio-oil. From both real 
world engineering and application point-of view, single fuel cell is an ultimate platform for catalyst performance test. Fig. 2a displays the cell polarization and power density curves of direct bio-oil AEMFC using the Pd/CNT, Ag/CNT, Au/CNT, and Pt/CNT anode catalysts. The open circuit voltage (OCV) of the direct bio-oil AEMFC with Pd/CNT was $0.84 \mathrm{~V}$, which is 0.04 $\mathrm{V}$ higher than that with $\mathrm{Ag} / \mathrm{CNT}, 0.05 \mathrm{~V}$ higher than that with Pt/CNT, and $0.09 \mathrm{~V}$ higher than that with Au/CNT. The peak power density (PPD) of the direct bio-oil AEMFC with Pd/CNT was $42.7 \mathrm{~mW} \mathrm{~cm}^{-2}$, which is $4.5 \%$ higher than that with $\mathrm{Pt} / \mathrm{CNT}, 8.7 \%$ higher than that with $\mathrm{Ag} / \mathrm{CNT}$, and $10.2 \%$ higher than that with Au/CNT. It is worth to mention that bio-oil, a complex mixture of more than 400 compounds, can be directly used as renewable fuel in AEMFCs without the need of catalytic conversion of bio-oil into fuel. Although our results indicate that there is no significant difference among the four noble catalysts (see Fig. 2a), Pd/CNT anode catalyst shows slightly higher fuel cell performance than the others. This is consistent with well-known understanding that $\mathrm{Pd}$ electrocatalysts are exclusively active for alcohol oxidation reaction and hydrogen oxidation in alkaline media [40, 41]. We hypothesize the current generated on $\mathrm{Pd} / \mathrm{CNT}$ is mainly attributed to the oxidation of levoglucosan and partially to oxidizing other compounds present in the bio-oil, especially sugars and alcohols. Ag is well-known for electrochemically catalyzing the carbonyl group (aldehyde and ketone) oxidation reaction more efficiently than $\mathrm{Pt} / \mathrm{CNT}, \mathrm{Pd} / \mathrm{CNT}$, and $\mathrm{Au} / \mathrm{CNT}$ [42]. Therefore, the current generated on Ag/CNT may be attributed to the Ag nanoparticle's electrocatalytic activity of aldehyde groups present in the bio-oil. We studied electrocatalytic oxidation of the model biomass molecule hydroxymethylfurfural (HMF), and found that $\mathrm{Au}$ greatly favors aldehyde oxidation over alcohol oxidation, but high electrode potentials are required for further oxidation of alcohol groups with $\mathrm{Au}$ [43], these preferences may also exist in complicated bio-oil electro- 
oxidation processes. It is well known that $\mathrm{Pt}$ is active to organic molecules electro-oxidation and can even facilitate spontaneous breakage of C-C bonds $[44,45]$. The direct fast pyrolysis bio-oil fuel cell with all the four catalysts Pd/CNT, $\mathrm{Ag} / \mathrm{CNT}$, Au/CNT, and Pt/CNT shows quite high open circuit voltage (OCV), conforming the overpotential to be sufficiently low to deliver current. This is because the catalysts can catalytically oxidize few of the compounds with their favored functional groups in the bio-oil. More than one functional group and highly active compounds in bio-oil impulsively play a significant role towards achieving AEMFC performance. We have demonstrated $\mathrm{Au} / \mathrm{C}$ with different particle sizes (3.0 nm vs $4.7 \mathrm{~nm}$ ); no obvious difference was observed between two DGFC with $\mathrm{Au} / \mathrm{C}$ with particle sizes of $3.0 \mathrm{~nm}$ and $\mathrm{Au} / \mathrm{C}$ with $4.7 \mathrm{~nm}$ [46]. For a direct pyrolysis bio-oil fuel cell, we similarly do not observe any apparent particle size effect on fuel cell performance. Future research will be to examine the bio-oil composition change due to electro-oxidation, so as to identify the main reactive components over the four catalysts, thus better bimetallic electrocatalysts may be rationally designed to achieve higher fuel cell power density.

\subsubsection{Effect of temperature on AEMFC performance}

Fig. 2b shows the cell polarization and power density curves of direct bio-oil AEMFC with Pd/CNT operated at various temperatures; the cell performance increased as the temperature increased over the whole current density range. In particular, the limiting current density increased from 120 to $290 \mathrm{~mA} \mathrm{~cm}{ }^{-2}$ when the temperature was increased from $25^{\circ} \mathrm{C}$ to $80^{\circ} \mathrm{C}$. This increase in temperature enhances the electrochemical kinetics of both the bio-oil oxidation reactions at the anode and the oxygen reduction reaction (ORR) at the cathode. The OCVs of direct bio-oil AEMFC operating at $25,40,60$ and $80^{\circ} \mathrm{C}$ were $0.66,0.72,0.79$, and $0.81 \mathrm{~V}$, while the PPDs were $12.4,17.1,25.2$, and $34.0 \mathrm{~mW} \mathrm{~cm}^{-2}$, respectively. In addition, the electrolyte 
conductivity increases with increasing temperature, reducing the ohmic loss, as shown by the cell resistance in Fig. S4a of SI. It has been demonstrated that the cell resistance is decreased as the temperature is increased and the resulting cell performance is improved. Furthermore, both biooil and oxygen transport diffusivities increase with an increased temperature, resulting in low mass transport polarization, so the cell performance increases as the temperature is increased; this can be attributed to faster electrochemical kinetics, increased conductivity of hydroxyl ions, and enhanced mass transfer.

\subsubsection{Effect of $\mathrm{KOH}$ concentration on AEMFC performance}

As shown in Fig. 2c, the fuel cell performance in terms of cell voltage increases from 1.0 to $6.0 \mathrm{M}$ with increasing $\mathrm{KOH}$ concentration, then decreases as the $\mathrm{KOH}$ concentration further increases beyond 6.0 M. The peak power densities plotted against $\mathrm{KOH}$ concentration exhibits a volcano-type behavior. In general, an increase in electrolyte alkalinity leads to higher local $\mathrm{OH}^{-}$ concentration at the anode catalyst layer and higher $\mathrm{OH}$ coverage on the catalyst surface, facilitating electrochemical kinetics [47-50]. The electrical conductivity of the $\mathrm{KOH}$ water solution will first increase and then decrease as $\mathrm{KOH}$ increases from $0 \mathrm{M}$ to $12.0 \mathrm{M}$; it reaches its maximum value at 7.0-8.0 $\mathrm{M}$ [51]. Thereupon, the single cell IR decreases as $\mathrm{KOH}$ concentration changes from $0 \mathrm{M}$ to $8.0 \mathrm{M}$ and then increases when $\mathrm{KOH}$ concentration further increases beyond $8.0 \mathrm{M}$, as shown in Fig. S4b of SI. If the $\mathrm{KOH}$ concentration was further increased beyond $8.0 \mathrm{M}$, large $\mathrm{KOH}$ concentration would have led to an excessive surface coverage with hydroxyl ions, thereby decreasing the number of active catalytic sites available for bio-oil absorption and causing the IR to increase while the cell voltage and associated performance declined. The maximum $\mathrm{KOH}$ concentration is limited due to its solubility in bio-oil solution. It is known that in AEMFC the internal resistance is affected by both anode and cathode membrane 
due to the conductive resistance of hydroxyl anions from cathode to anode side. We previously reported this phenomenon [29], stating that a surplus of hydroxyl anions will prevent fuel from being sufficiently absorbed onto the active sites of an anode catalyst layer. High internal resistance is thus observed at beyond $8.0 \mathrm{M} \mathrm{KOH}$ due to the mass transfer issue becoming dominant. In summary, it can be concluded that single-cell performance increases with an increased $\mathrm{KOH}$ concentration until reaches a maximum limitation by the excessive hydroxyl ions coverage and decrease in the number of active catalytic sites.

\subsubsection{Effect of bio-oil concentration on AEMFC performance}

Fig. 2d illustrates that fuel performance and cell voltage increase with higher concentration of bio-oil at low current density as the local bio-oil concentration increases from $5.0 \mathrm{wt} \%$ to $30.0 \mathrm{wt} \%$ (equivalent levoglucosan concentration: $0.3 \mathrm{M}$ ). A further increase in the bio-oil concentration from $30.0 \mathrm{wt} \%$ to $60.0 \mathrm{wt} \%$ causes the cell voltage to decrease gradually in the low current density region. In addition, higher bio-oil concentration causes the more active sites of the anode catalyst to be covered by the bio-oil, blocking the adsorption of hydroxide on the active sites and leading to a decrease in performance. Essentially, the kinetics of the oxidation reaction depends on the surface concentration of both bio-oil and hydroxide ions. At higher current densities the cell voltage dropped more rapidly for $5.0 \mathrm{wt} \%$ concentration than with 20 to $40 \mathrm{wt} \%$ concentration because a $5.0 \mathrm{wt} \%$ supplies a mass transfer rate insufficient to produce high current densities; the bio-oil concentration in the anode catalyst layer is simply inadequate. Cell performance also declines when the bio-oil level is higher than $30 \mathrm{wt} \%$; this concentration of bio-oil alleviates diffusion limitations due to the higher driving force required for mass transport. However, when the bio-oil concentration is increased, the electrolyte viscosity increases, decreasing the $\mathrm{OH}^{-}$mobility and conductivity of the electrolyte. An increase 
in cell resistance with increasing bio-oil concentration is shown in Fig. S4c of SI. The higher biooil concentration ( $40.0 \mathrm{wt} \%$ to $60.0 \mathrm{wt} \%$ ) creates a barrier for $\mathrm{OH}^{-}$transfer by covering active sites in the anode catalyst layer, leading to an extreme increase in cell resistance, from 198.3 $\mathrm{mOhm}$ to $316.2 \mathrm{mOhm}$. This extreme cell resistance causes a reduction in the cell voltage and the cell performance is thus reduced. In summary, OCV and cell performance increases with an increase of bio-oil concentration of up to $30 \%$ because the local bio-oil concentration in the catalyst layer is too low. However, when the bio-oil fuel solution is too high at the anode catalyst layer, the coverage of hydroxide ions on catalytic sites is reduced, producing dramatic decreases in cell performance and cell voltage.

\subsection{Electrooxidation of levoglucosan over various catalysts in half-cell}

Since levoglucosan has been identified as the major component present in bio-oil, the activity of electrocatalytic oxidation of levoglucosan on $\mathrm{Pd} / \mathrm{CNT}, \mathrm{Ag} / \mathrm{CNT}, \mathrm{Au} / \mathrm{CNT}$, and $\mathrm{Pt} / \mathrm{CNT}$ was investigated in a three electrode half-cell system. The reason for this investigation was to further understand the catalyst mechanism of an identified levoglucosan in bio-oil. Fig. 3 shows that the $\mathrm{Pd} / \mathrm{CNT}$ catalyst exhibited higher current density than $\mathrm{Ag} / \mathrm{CNT}, \mathrm{Au} / \mathrm{CNT}$, and $\mathrm{Pt} / \mathrm{CNT}$ at low potential (below $0.0 \mathrm{~V}$ ) despite its small hydrogen adsorption-desorption properties. Furthermore, Pd/CNT exhibited a more negative onset potential (-0.4 V) compared to those of Pt/CNT (-0.3 V), Au/CNT (-0.05 V), and Ag/CNT (0.1 V). The sequence of onset potential in the forward scan was $\mathrm{Pd} / \mathrm{CNT}<\mathrm{Pt} / \mathrm{CNT}<\mathrm{Au} / \mathrm{CNT}<\mathrm{Ag} / \mathrm{CNT}$; this is consistent with AEMFC performance results. However, a low anode overpotential is preferred in the fuel cell operation, and the low potential region $(<0.7 \mathrm{~V}$ vs. RHE vs. $-0.2 \mathrm{~V}$ vs. $\mathrm{Hg} / \mathrm{HgO})$ is more important than the resulting high potential region of $\mathrm{CV}$. Au/CNT demonstrates an extremely high peak current density at high potential, indicating that the Au catalyst can maintain its 
activity over a wide applied potential range. Au/CNT, Ag/CNT and Pt/CNT catalysts displaced very little to no activity toward levoglucosan electro-oxidation at lower potentials.

\subsection{Electrooxidation of high purity sugars over Pd/CNT in half-cell and AEMFC}

To compare the performance of electrocatalytic oxidation of sugars, the activity of electrocatalytic oxidation of high purity sugars such as glucose, levoglucosan and sucrose on Pd/CNT was investigated in both half-cell and single fuel cell configurations. Fig. 4 shows that the current density for glucose was slightly higher than that for levoglucosan. Generated current density from glucose and levoglucosan oxidation was much greater than that from sucrose oxidation. Glucose and levoglucosan are both $\mathrm{C}_{6}$ molecules and can be adsorbed on the thin catalyst film faster, exposing more active sites to the fuel than the $\mathrm{C}_{12}$ molecules of sucrose. Smaller species generally have better mass transfer and can be adsorbed faster on the catalyst thin film compared to bigger species with poor mass transfer $[52,53]$. Sucrose is adsorbed more slowly on the active sites of the catalyst, further diminishing occurrence of fully oxidation to occur. Furthermore, electrooxidation of glucose exhibited more negative onset potential (-0.6 V) compared to levoglucosan $(-0.4 \mathrm{~V})$, and sucrose $(-0.3 \mathrm{~V})$; this may be attributed to the relatively more active aldehyde group in glucose.

Fig. 5 shows the cell polarization and power density curves of direct high-purity sugarfed AEMFCs with Pd/CNT as an anode catalyst. The OCV of direct high-purity sugar-fed AEMFC operating with glucose, levoglucosan, and sucrose are $0.96,0.83$, and $0.79 \mathrm{~V}$, while the

PPD values are 145.5, 73.6, and $49.1 \mathrm{~mW} \mathrm{~cm}^{-2}$, respectively. As demonstrated, the output power dramatically drops when AEMFC is fueled with the higher carbon-chain sugar such as sucrose. These single cell results on direct high-purity sugar-derived AEMFCs are consistent with our previous findings for half-cells. Glucose and levoglucosan are both adsorbed on the anode 
catalyst layer faster than sucrose, revealing that glucose and levoglucosan has a higher permeability that facilitates the species transport, lowering transport resistance, resulting in the enhanced mass transport, thus higher peak power density was obtained.

\subsection{The relationship between fast pyrolysis bio-oil fuel cell and sugar fuel cell}

The peak power density of bio-oil fuel cell is about $\sim 1.2$ to 3 times lower than that of a high-purity sugar fuel cell with the same Pd loading, considering that the equivalent sugar content in bio-oil is only about $0.3 \mathrm{M}$ sugar. Many unknown and highly active compounds containing aldehyde, furans, phenolics, and ketone groups in bio-oil may play significantly different roles in performance of AEMFCs. The generated current in direct bio-oil fuel cells using all four noble metals is attributed to many spontaneous and simultaneous oxidation processes. It is interesting to find that the inert impurities of bio-oil do not poison the noble metal catalyst and therefore do not deactivate the catalyst. The limiting current densities on the direct bio-oil AEMFC also do not significantly drop with enormous variations (Figure 2a), indicating that complex mixtures of bio-oil lead similarly do not have poor mass transfer phenomenon with all tested catalysts. Our recent work further shows that using $\mathrm{N}$ and S-doped mesoporous carbon as metal-free cathode catalysts [54] and a robust PTFE porous separator [55] as an electrolyte membrane can significantly reduce the cost of the fuel cell, while maintaining similar fuel cell performance. Overall, we have demonstrated a direct bio-oil fuel cell can directly generate electrical energy from complex bio-oil without any purification process. The electrical power density is nearly 2 orders of magnitude greater than reported enzymatic biofuel cell with highpurity derived sugars $[56,57]$. Our results may provide a new route to directly generating high power density electricity from bio-oil, and further offer an electrochemical processing approach for bio-oil upgrading to valuable chemicals from the bio-oil fuel cell anode downstream. 


\subsection{Research and Development efforts for the future direct pyrolysis bio-oil fuel cell}

This new technology suggests that fast pyrolysis bio-oil as alternative fuel for fuel cells and crude feedstocks expand fuel sources for fuel cell applications. Direct fast pyrolysis bio-oil fuel cells can be economically beneficial if "bio-oil upgrading" and "electricity generation" can be simultaneously achieved. Efficient and direct production of electricity from raw biomass feedstock can be considered as a supplement to current thermochemical, chemical, and biological methodologies for transforming biomass to energy and chemicals, thus reducing subsequent purification costs. Techno-economic analysis (TEA) can provide economic indicators for future bio-oil fuel-cell materials and technology development. There are, however, major areas that should be improved if bio-oil is to become a reliable energy source in fuel cell technologies. These research include: (i) develop advanced anode catalysts that can improve the electrocatalytic oxidation and stabilization of bio-oil, while alleviating catalyst poisoning and degradation, (ii) explore low cost efficient cathode catalyst that is active to oxygen reduction reaction but inactive towards bio-oil, (iii) study reliable, inexpensive anion exchange membranes with minimized reactant crossover, and (iv) understand the reaction steps and pathways so as to design more efficient electrocatalytic processes. This novel electrochemical system concept will help renovate how we produce, transport, or use energy, and facilitate combining renewable electricity and carbon sources to achieve green electrocatalytic manufacturing and electrical energy generation.

\section{Conclusions}

In this work, we have demonstrated that bio-oil can be directly used as a fuel for AEMFCs at low temperatures. A direct bio-oil AEMFC using CNT supported noble metal nanoparticles (Pt/CNT, $\mathrm{Pd} / \mathrm{CNT}, \mathrm{Au} / \mathrm{CNT}$, or $\mathrm{Ag} / \mathrm{CNT}$ ) as an anode catalyst achieved a remarkably high peak power 
density of $42.7 \mathrm{~mW} \mathrm{~cm}^{-2}$ at $80^{\circ} \mathrm{C}$ and ambient pressure. In addition, the effects of variation in operating conditions, including bio-oil concentration, temperature, and $\mathrm{KOH}$ concentration, were investigated to further enhance performance of the fuel cell. The highest performance was achieved with $6.0 \mathrm{M} \mathrm{KOH}$ and $30 \mathrm{wt} \%$ bio-oil at $80^{\circ} \mathrm{C}$ on $\mathrm{Pd} / \mathrm{CNT}$. The experimental results showed that cell performance improves with optimized operating parameters due to the improved kinetics of ORR, and an increase in bio-oil diffusivity and hydroxyl ion conductivity. The compositional analysis of bio-oil was performed using HPLC, GC, and IC analytical techniques. Levoglucosan was found to be the major identified sugar compound of the bio-oil, with 11.1 wt\%. The electrocatalytic activities of four noble previous catalysts (Pd/CNT, Ag/CNT, $\mathrm{Au} / \mathrm{CNT}$, and Pt/CNT) on highly-purified sugar (levoglucosan) identified by cyclic voltammetry showed that $\mathrm{Pd} / \mathrm{CNT}$ had the highest activity in the low potential region with lowest onset potential. The relationship between pyrolysis bio-oil and a pure sugar fuel cell shows that bio-oil fuel cell is about $\sim 1.2$ to 3 times lower than the high purity sugar fed fuel cell. The direct bio-oil AEMFC, however, has potential due to its capability of using unrefined biomass-derived feedstock for fuel.

\section{Acknowledgements}

We acknowledge financial support from the US National Science Foundation (CBET1501124) and the Iowa State University startup fund. The authors would like to thank Ryan Smith for supplying bio-oil and John Matthiesen, and Dr. Robert L. Johnson of Iowa State University for assistance in understanding NMR data analysis. W. Li is grateful to his Richard Seagrave Professorship and the Iowa Energy Center Opportunity Grant fund. 


\section{References}

[1] Liu W, Mu W, Deng Y. High-Performance Liquid-Catalyst Fuel Cell for Direct Biomass-into-Electricity Conversion. Angewandte Chemie 2014;126:13776-80.

[2] Tuck CO, Pérez E, Horváth IT, Sheldon RA, Poliakoff M. Valorization of Biomass: Deriving More Value from Waste. Science 2012;337:695-9.

[3] Administration El. U.S. Department of energy. Annual Energy Outlook 2009.

[4] Administration El. U.S. Department of energy. Electric Power Annual 2016.

[5] Mohan D, Pittman CU, Steele PH. Pyrolysis of Wood/Biomass for Bio-oil: A Critical Review. Energy \& Fuels 2006;20:848-89.

[6] Tsai WT, Lee MK, Chang YM. Fast pyrolysis of rice straw, sugarcane bagasse and coconut shell in an induction-heating reactor. Journal of Analytical and Applied Pyrolysis 2006;76:230-7.

[7] Boudghene Stambouli A, Traversa E. Fuel cells, an alternative to standard sources of energy. Renewable and Sustainable Energy Reviews 2002;6:295-304.

[8] Lamy C, Coutanceau C, Leger J-M. The Direct Ethanol Fuel Cell: a Challenge to Convert Bioethanol Cleanly into Electric Energy. Catalysis for Sustainable Energy Production: Wiley-VCH Verlag GmbH \& Co. KGaA; 2009. p. 1-46.

[9] Wee J-H. Applications of proton exchange membrane fuel cell systems. Renewable and Sustainable Energy Reviews 2007;11:1720-38.

[10] Matsuoka K, Iriyama Y, Abe T, Matsuoka M, Ogumi Z. Alkaline direct alcohol fuel cells using an anion exchange membrane. Journal of Power Sources 2005;150:27-31.

[11] Coutanceau C, Demarconnay L, Lamy C, Léger JM. Development of electrocatalysts for solid alkaline fuel cell (SAFC). Journal of Power Sources 2006;156:14-9.

[12] Yang Y-L, Liu X-H, Hao M-Q, Zhang P-P. Performance of a low-cost direct glucose fuel cell with an anion-exchange membrane. International Journal of Hydrogen Energy 2015;40:10979-84.

[13] Hao M, Liu X, Feng M, Zhang P, Wang G. Generating power from cellulose in an alkaline fuel cell enhanced by methyl viologen as an electron-transfer catalyst. Journal of Power Sources 2014;251:222-8. [14] Zhang Z, Xin L, Li W. Supported gold nanoparticles as anode catalyst for anion-exchange membranedirect glycerol fuel cell (AEM-DGFC). International Journal of Hydrogen Energy 2012;37:9393-401. [15] Czernik S, Bridgwater AV. Overview of Applications of Biomass Fast Pyrolysis Oil. Energy \& Fuels 2004;18:590-8.

[16] Huber GW, Iborra S, Corma A. Synthesis of Transportation Fuels from Biomass: Chemistry, Catalysts, and Engineering. Chemical Reviews 2006;106:4044-98.

[17] Mullen CA, Boateng AA. Chemical Composition of Bio-oils Produced by Fast Pyrolysis of Two Energy Cropst. Energy \& Fuels 2008;22:2104-9.

[18] Oasmaa A, Czernik S. Fuel Oil Quality of Biomass Pyrolysis OilsState of the Art for the End Users. Energy \& Fuels 1999;13:914-21.

[19] Pollard AS, Rover MR, Brown RC. Characterization of bio-oil recovered as stage fractions with unique chemical and physical properties. Journal of Analytical and Applied Pyrolysis 2012;93:129-38. [20] Rover MR, Johnston PA, Jin T, Smith RG, Brown RC, Jarboe L. Production of Clean Pyrolytic Sugars for Fermentation. ChemSusChem 2014;7:1662-8.

[21] Wang S, Gu Y, Liu Q, Yao Y, Guo Z, Luo Z, et al. Separation of bio-oil by molecular distillation. Fuel Processing Technology 2009;90:738-45. 
[22] Simões M, Baranton S, Coutanceau C. Electro-oxidation of glycerol at Pd based nano-catalysts for an application in alkaline fuel cells for chemicals and energy cogeneration. Applied Catalysis B:

Environmental 2010;93:354-62.

[23] Zhang Z, Xin L, Qi J, Chadderdon DJ, Sun K, Warsko KM, et al. Selective electro-oxidation of glycerol to tartronate or mesoxalate on Au nanoparticle catalyst via electrode potential tuning in anion-exchange membrane electro-catalytic flow reactor. Applied Catalysis B: Environmental 2014;147:871-8.

[24] Zhang Z, Xin L, Sun K, Li W. Pd-Ni electrocatalysts for efficient ethanol oxidation reaction in alkaline electrolyte. International Journal of Hydrogen Energy 2011;36:12686-97.

[25] Zainoodin AM, Kamarudin SK, Masdar MS, Daud WRW, Mohamad AB, Sahari J. High power direct methanol fuel cell with a porous carbon nanofiber anode layer. Applied Energy 2014;113:946-54.

[26] Xin L, Zhang Z, Qi J, Chadderdon D, Li W. Electrocatalytic oxidation of ethylene glycol (EG) on supported Pt and Au catalysts in alkaline media: Reaction pathway investigation in three-electrode cell and fuel cell reactors. Applied Catalysis B: Environmental 2012;125:85-94.

[27] Liu Z, Huang L, Zhang L, Ma H, Ding Y. Electrocatalytic oxidation of d-glucose at nanoporous Au and Au-Ag alloy electrodes in alkaline aqueous solutions. Electrochimica Acta 2009;54:7286-93.

[28] Calabrese Barton S, Gallaway J, Atanassov P. Enzymatic Biofuel Cells for Implantable and Microscale Devices. Chemical Reviews 2004;104:4867-86.

[29] Qi J, Xin L, Zhang Z, Sun K, He H, Wang F, et al. Surface dealloyed PtCo nanoparticles supported on carbon nanotube: facile synthesis and promising application for anion exchange membrane direct crude glycerol fuel cell. Green Chemistry 2013;15:1133-7.

[30] Zhang Z, Xin L, Qi J, Chadderdon DJ, Li W. Supported Pt, Pd and Au nanoparticle anode catalysts for anion-exchange membrane fuel cells with glycerol and crude glycerol fuels. Applied Catalysis B:

Environmental 2013;136-137:29-39.

[31] Qi J, Xin L, Chadderdon DJ, Qiu Y, Jiang Y, Benipal N, et al. Electrocatalytic selective oxidation of glycerol to tartronate on $\mathrm{Au} / \mathrm{C}$ anode catalysts in anion exchange membrane fuel cells with electricity cogeneration. Applied Catalysis B: Environmental 2014;154-155:360-8.

[32] Qi J, Benipal N, Chadderdon DJ, Huo J, Jiang Y, Qiu Y, et al. Carbon nanotubes as catalysts for direct carbohydrazide fuel cells. Carbon 2015;89:142-7.

[33] Qi J, Benipal N, Wang H, Chadderdon DJ, Jiang Y, Wei W, et al. Back Cover: Metal-Catalyst-Free Carbohydrazide Fuel Cells with Three-Dimensional Graphene Anodes (ChemSusChem 7/2015).

ChemSusChem 2015;8:1288-.

[34] Choi YS, Johnston PA, Brown RC, Shanks BH, Lee K-H. Detailed characterization of red oak-derived pyrolysis oil: Integrated use of GC, HPLC, IC, GPC and Karl-Fischer. Journal of Analytical and Applied Pyrolysis 2014;110:147-54.

[35] Zhang Z, More KL, Sun K, Wu Z, Li W. Preparation and Characterization of PdFe Nanoleaves as Electrocatalysts for Oxygen Reduction Reaction. Chemistry of Materials 2011;23:1570-7.

[36] Li W, Waje M, Chen Z, Larsen P, Yan Y. Platinum nanopaticles supported on stacked-cup carbon nanofibers as electrocatalysts for proton exchange membrane fuel cell. Carbon 2010;48:995-1003. [37] Li W, Zhou W, Li H, Zhou Z, Zhou B, Sun G, et al. Nano-stuctured Pt-Fe/C as cathode catalyst in direct methanol fuel cell. Electrochimica Acta 2004;49:1045-55.

[38] Branca C, Giudicianni P, Di Blasi C. GC/MS Characterization of Liquids Generated from LowTemperature Pyrolysis of Wood. Industrial \& Engineering Chemistry Research 2003;42:3190-202. [39] Pittman CU, Mohan D, Eseyin A, Li Q, Ingram L, Hassan E-BM, et al. Characterization of Bio-oils Produced from Fast Pyrolysis of Corn Stalks in an Auger Reactor. Energy \& Fuels 2012;26:3816-25. [40] Bianchini C, Shen PK. Palladium-Based Electrocatalysts for Alcohol Oxidation in Half Cells and in Direct Alcohol Fuel Cells. Chemical Reviews 2009;109:4183-206. 
[41] Wang H, Xu C, Cheng F, Zhang M, Wang S, Jiang SP. Pd/Pt core-shell nanowire arrays as highly effective electrocatalysts for methanol electrooxidation in direct methanol fuel cells. Electrochemistry Communications 2008;10:1575-8.

[42] Aoun SB, Bang GS, Koga T, Nonaka Y, Sotomura T, Taniguchi I. Electrocatalytic oxidation of sugars on silver-UPD single crystal gold electrodes in alkaline solutions. Electrochemistry Communications 2003;5:317-20.

[43] Chadderdon DJ, Xin L, Qi J, Qiu Y, Krishna P, More KL, et al. Electrocatalytic oxidation of 5hydroxymethylfurfural to 2,5-furandicarboxylic acid on supported $\mathrm{Au}$ and Pd bimetallic nanoparticles. Green Chemistry 2014;16:3778-86.

[44] Lamy* C, Coutanceau C. Chapter 1 Electrocatalysis of Alcohol Oxidation Reactions at Platinum Group Metals. Catalysts for Alcohol-Fuelled Direct Oxidation Fuel Cells: The Royal Society of Chemistry; 2012. p. 1-70.

[45] Li M, Liu P, Adzic RR. Platinum Monolayer Electrocatalysts for Anodic Oxidation of Alcohols. The Journal of Physical Chemistry Letters 2012;3:3480-5.

[46] Qi J, Xin L, Chadderdon DJ, Qiu Y, Jiang Y, Benipal N, et al. Electrocatalytic selective oxidation of glycerol to tartronate on $\mathrm{Au} / \mathrm{C}$ anode catalysts in anion exchange membrane fuel cells with electricity cogeneration. Applied Catalysis B: Environmental 2014;154-155:360-8.

[47] An L, Zhao TS, Shen SY, Wu QX, Chen R. Performance of a direct ethylene glycol fuel cell with an anion-exchange membrane. International Journal of Hydrogen Energy 2010;35:4329-35.

[48] Li YS, Zhao TS, Liang ZX. Performance of alkaline electrolyte-membrane-based direct ethanol fuel cells. Journal of Power Sources 2009;187:387-92.

[49] Park J-S, Park S-H, Yim S-D, Yoon Y-G, Lee W-Y, Kim C-S. Performance of solid alkaline fuel cells employing anion-exchange membranes. Journal of Power Sources 2008;178:620-6.

[50] Scott K, Yu E, Vlachogiannopoulos G, Shivare M, Duteanu N. Performance of a direct methanol alkaline membrane fuel cell. Journal of Power Sources 2008;175:452-7.

[51] Gilliam RJ, Graydon JW, Kirk DW, Thorpe SJ. A review of specific conductivities of potassium hydroxide solutions for various concentrations and temperatures. International Journal of Hydrogen Energy 2007;32:359-64.

[52] Becerik I, Kadirgan F. The electrocatalytic properties of palladium electrodes for the oxidation of $d$ glucose in alkaline medium. Electrochimica Acta 1992;37:2651-7.

[53] Parpot P, Kokoh KB, Belgsir EM, Le'Ger JM, Beden B, Lamy C. Electrocatalytic oxidation of sucrose: analysis of the reaction products. Journal of Applied Electrochemistry 1997;27:25-33.

[54] Qiu Y, Huo J, Jia F, Shanks BH, Li W. N- and S-doped mesoporous carbon as metal-free cathode catalysts for direct biorenewable alcohol fuel cells. Journal of Materials Chemistry A 2016;4:83-95.

[55] Benipal N, Qi J, Gentile JC, Li W. Direct Glycerol Fuel Cell with Polytetrafluoroethylene (PTFE) Thin Film Separator Manuscript in progress

[56] Arechederra RL, Treu BL, Minteer SD. Development of glycerol/O2 biofuel cell. Journal of Power Sources 2007;173:156-61.

[57] Zebda A, Cosnier S, Alcaraz JP, Holzinger M, Le Goff A, Gondran C, et al. Single Glucose Biofuel Cells Implanted in Rats Power Electronic Devices. Scientific Reports 2013;3:1516. 


\section{Figure Captions:}

Fig. 1. TEM and histograms of (a) Pt/CNT, (b) Pd/CNT, (c) Au/CNT, (d) Ag/CNT, and (e) XRD patterns of Pt/CNT, Pd/CNT, Au/CNT, and Ag/CNT.

Fig. 2. A-D polarization and power density curves of bio-oil AEMFC with noble metal anode catalyst and Fe-based Acta 4020 cathode catalyst, (a) comparison of different noble metal $\mathrm{Pd} / \mathrm{CNT}, \mathrm{Pt} / \mathrm{CNT}, \mathrm{Au} / \mathrm{CNT}$, and $\mathrm{Ag} / \mathrm{CNT}$ as anode catalyst on the fuel cell performance at $80^{\circ} \mathrm{C}$; anode fuel: $6.0 \mathrm{M} \mathrm{KOH}+30.0 \mathrm{wt} \%$ bio-oil (equivalent levoglucosan concentration: $0.3 \mathrm{M}$ ), b) effect of temperature on fuel cell performance with Pd/CNT anode catalyst; anode fuel: $6.0 \mathrm{M}$ $\mathrm{KOH}+20 \mathrm{wt} \%$ bio-oil c) effect of $\mathrm{KOH}$ concentration on fuel cell performances with Pd/CNT anode catalyst at $60^{\circ} \mathrm{C}$; anode fuel: $20.0 \mathrm{wt} \%$ bio-oil, d) effect of bio-oil concentration on fuel cell performances with $\mathrm{Pd} / \mathrm{CNT}$ anode catalyst at $60^{\circ} \mathrm{C}$; $\mathrm{KOH}$ concentration $2.0 \mathrm{M}$.

Fig. 3. Cyclic voltammograms of levoglucosan oxidation reaction on Pd/CNT, Ag/CNT, $\mathrm{Au} / \mathrm{CNT}$, and Pt/CNT catalysts in $1.0 \mathrm{M} \mathrm{KOH}+0.1 \mathrm{M}$ levoglucosan, $50 \mathrm{mV} \mathrm{s}^{-1}, 25^{\circ} \mathrm{C}$.

Fig. 4. Cyclic Voltammograms of Pd/CNT catalyst on electrocatalytic oxidation of glucose, levoglucosan, and sucrose in $1.0 \mathrm{M} \mathrm{KOH}+0.1 \mathrm{M}$ fuel, $50 \mathrm{mV} \mathrm{s}^{-1}, 25^{\circ} \mathrm{C}$.

Fig. 5. The polarization and power density curves of direct high-purity sugars derived AEMFC with Pd/CNT anode catalyst; Fe-based Acta 4020 cathode catalyst; anode fuel: $6.0 \mathrm{M} \mathrm{KOH}+0.5$ $\mathrm{M}$ glucose, levoglucosan, and sucrose; $80^{\circ} \mathrm{C}$. 



Fig. 1. TEM and histograms of (a) Pt/CNT, (b) Pd/CNT, (c) Au/CNT, (d) Ag/CNT, and (e) XRD patterns of Pt/CNT, Pd/CNT, Au/CNT, and Ag/CNT. 

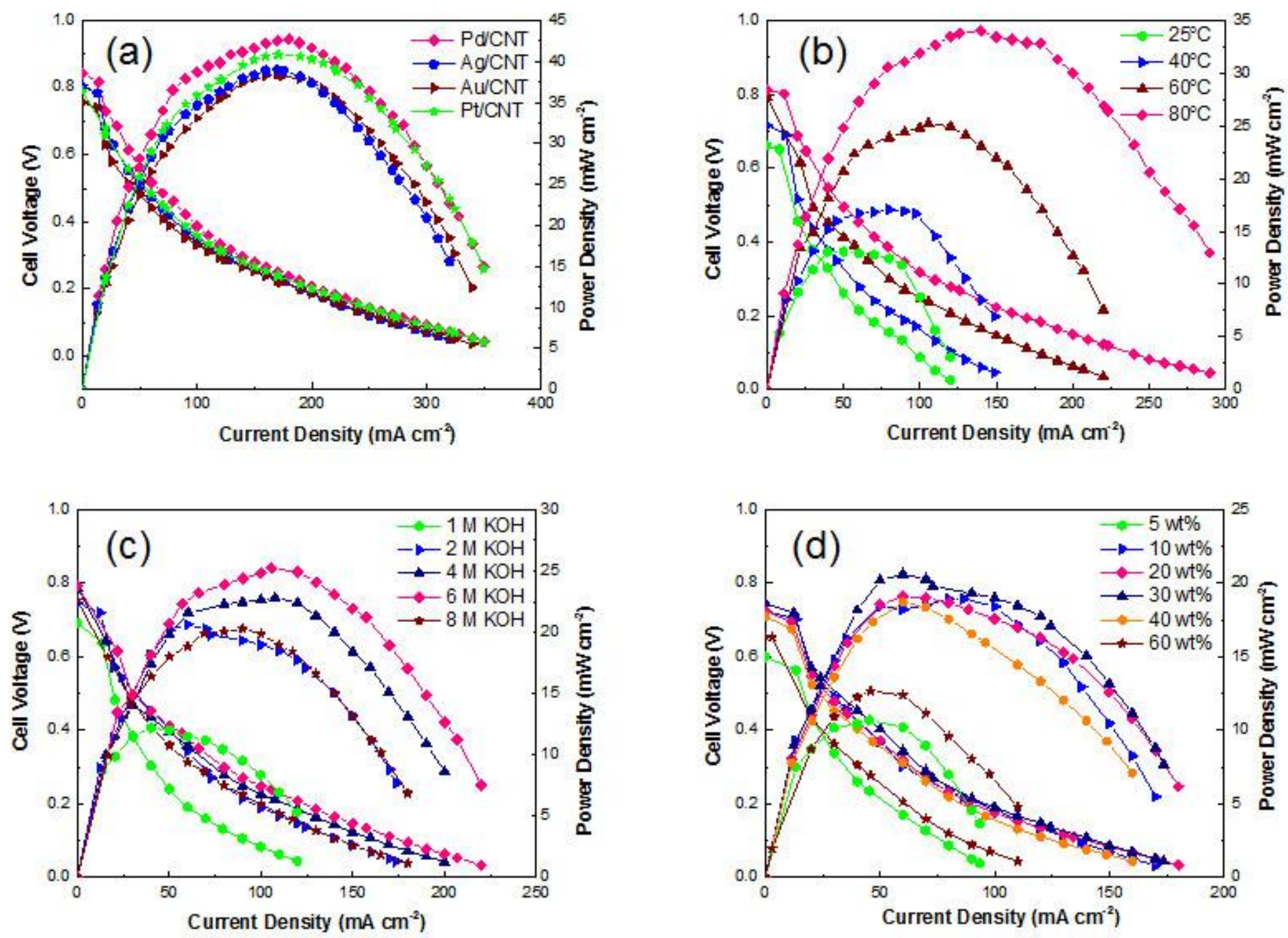

Fig. 2. a-d polarization and power density curves of bio-oil AEMFC with noble metal anode catalyst and Fe-based Acta 4020 cathode catalyst, (a) comparison of different noble metal $\mathrm{Pd} / \mathrm{CNT}, \mathrm{Pt} / \mathrm{CNT}, \mathrm{Au} / \mathrm{CNT}$, and $\mathrm{Ag} / \mathrm{CNT}$ as anode catalyst on the fuel cell performance at $80^{\circ} \mathrm{C}$; anode fuel: $6.0 \mathrm{M} \mathrm{KOH}+30.0 \mathrm{wt} \%$ bio-oil (equivalent sugar concentration: $0.30 \mathrm{M}$ ), b) effect of temperature on fuel cell performance with Pd/CNT anode catalyst; anode fuel: $6.0 \mathrm{M} \mathrm{KOH}+20$ wt\% bio-oil c) effect of $\mathrm{KOH}$ concentration on fuel cell performances with $\mathrm{Pd} / \mathrm{CNT}$ anode catalyst at $60^{\circ} \mathrm{C}$; anode fuel: $20.0 \mathrm{wt} \%$ bio-oil, d) effect of bio-oil concentration on fuel cell performances with $\mathrm{Pd} / \mathrm{CNT}$ anode catalyst at $60^{\circ} \mathrm{C}$; $\mathrm{KOH}$ concentration $2.0 \mathrm{M}$. 




Fig. 3. Cyclic voltammograms of levoglucosan oxidation reaction on $\mathrm{Pd} / \mathrm{CNT}, \mathrm{Ag} / \mathrm{CNT}$, $\mathrm{Au} / \mathrm{CNT}$, and Pt/CNT catalysts in $1.0 \mathrm{M} \mathrm{KOH}+0.1 \mathrm{M}$ levoglucosan, $50 \mathrm{mV} \mathrm{s}^{-1}, 25^{\circ} \mathrm{C}$. 


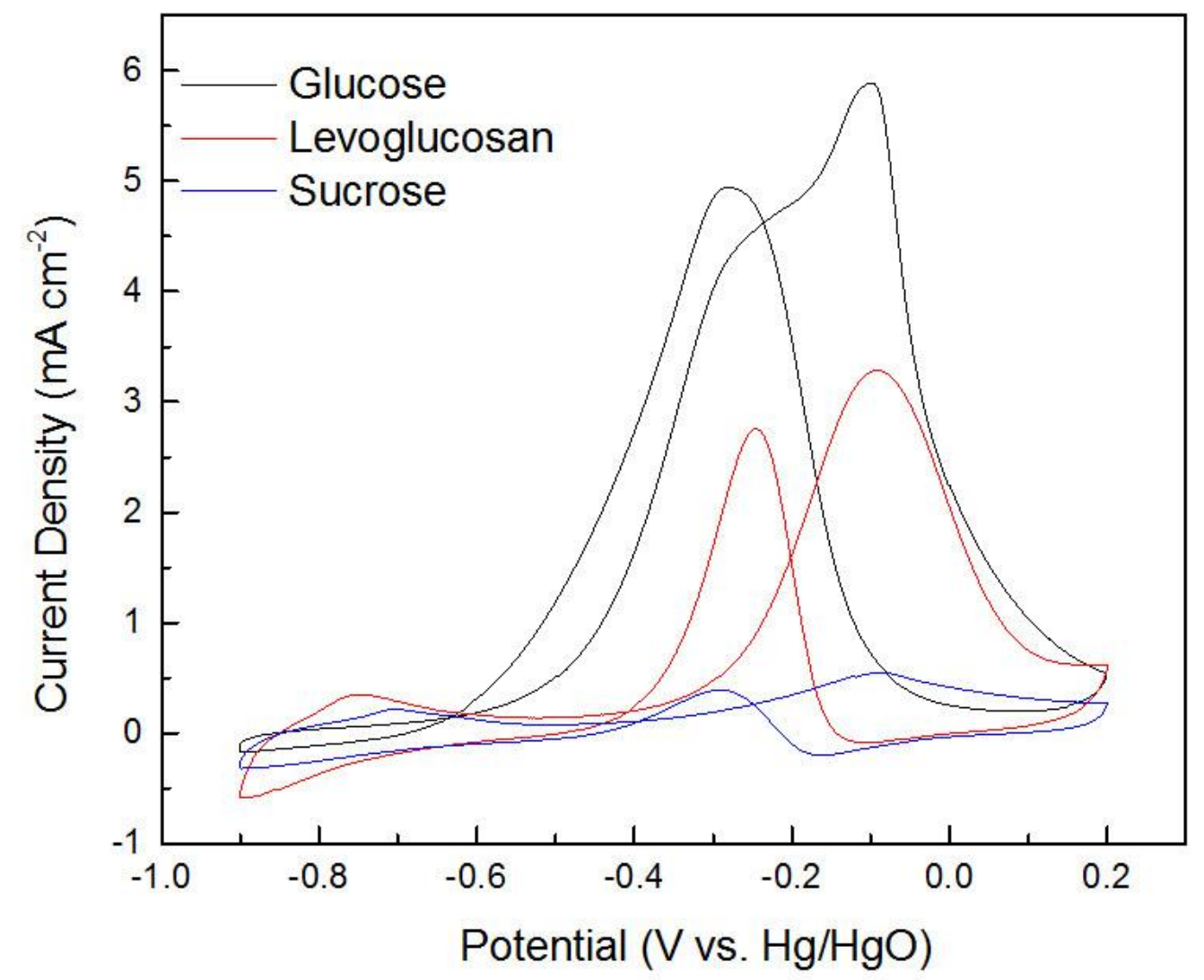

Fig. 4. Cyclic Voltammograms of $\mathrm{Pd} / \mathrm{CNT}$ catalyst on electrocatalytic oxidation of glucose, levoglucosan, and sucrose in $1.0 \mathrm{M} \mathrm{KOH}+0.1 \mathrm{M}$ fuel, $50 \mathrm{mV} \mathrm{s}^{-1}, 25^{\circ} \mathrm{C}$. 


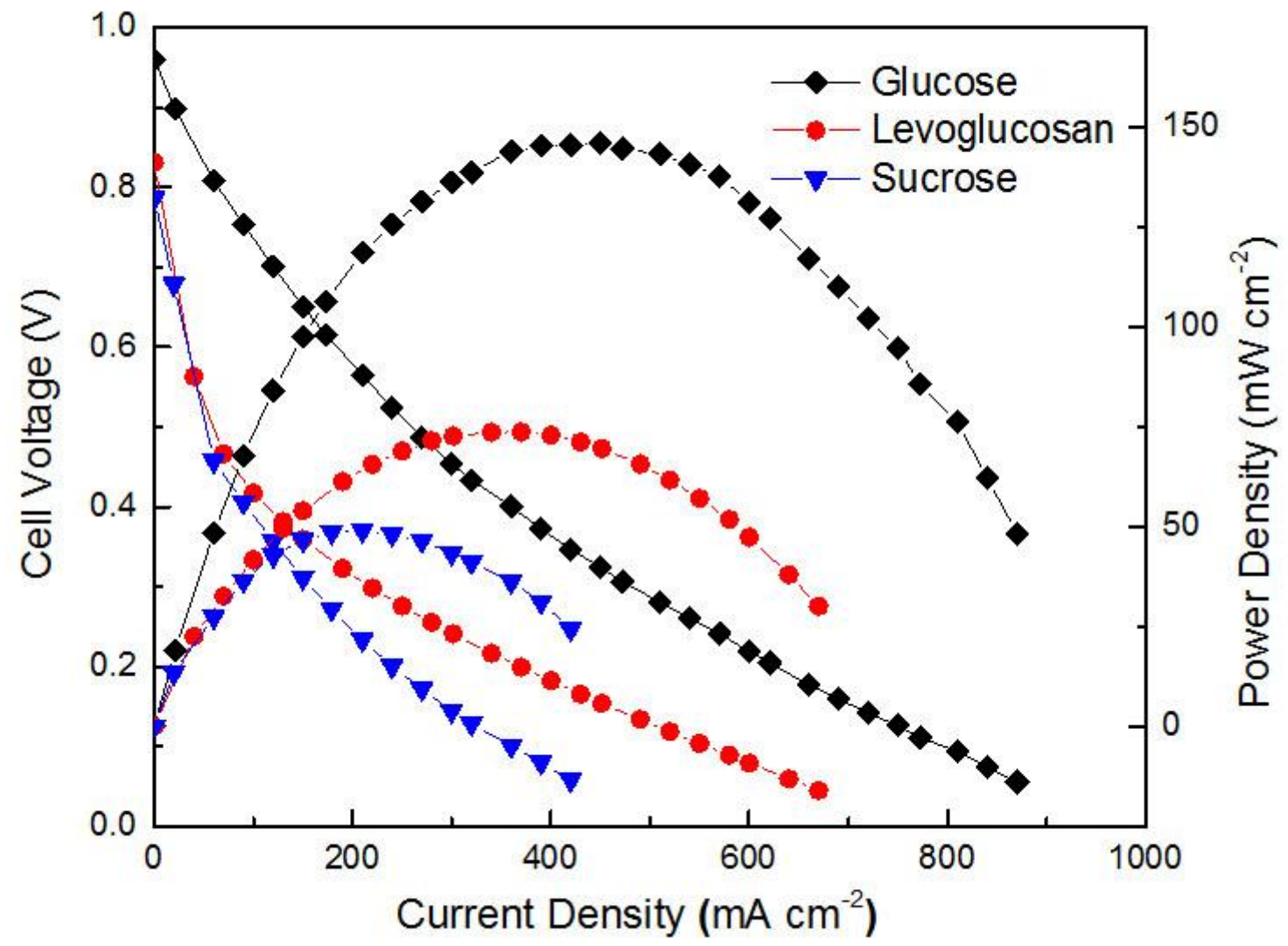

Fig. 5. The polarization and power density curves of direct high-purity sugars derived AEMFC with $\mathrm{Pd} / \mathrm{CNT}$ anode catalyst; Fe-based Acta 4020 cathode catalyst; anode fuel: $6.0 \mathrm{M} \mathrm{KOH}+0.5$ $\mathrm{M}$ glucose, levoglucosan, and sucrose; $80^{\circ} \mathrm{C}$. 


\section{Graphical Abstract}
